\title{
Morpa Weeping Lovegrass Produces More Beef
}

\section{MARVIN SHOOP, E. H. McILVAIN, AND P. W. VOIGT}

Highlight: Morpa, a new variety of weeping lovegrass (Eragrostis curvula (Schrad.) Nees), increased yearly gain per steer $33 \mathrm{lb}$, or $12 \%$, in a 3-year grazing comparison with Common weeping lovegrass at Woodward, Oklahoma. Because steer gains were greater, Morpa produced $\$ 12.00$, or $170 \%$, more profit per acre. Also, Morpa had the same high carrying capacity as Common; was equally adapted to withstand drouth; and required the same high level of cultural and grazing management. Morpa was slightly less winterhardy than Common.

Weeping lovegrass (Eragrostis curvula (Schrad.) Nees) produces about three to five times more usable forage at Woodward, Okla., than does native range. Weeping lovegrass (lovegrass) also is well adapted to the climate and to the sandy soils of the Southern Great Plains. Lovegrass establishes easily, persists well under grazing, and responds to such improvement practices as nitrogen fertilization, rotational grazing, and mowing of overmature forage. However, lovegrass declines rapidly in palatability as it matures, and special management is required to maintain good cattle gains.

In palatability trials at Woodward, steers preferred one strain of lovegrass, P. I. 208994 (Voigt et al., 1970). This strain was named 'Morpa' to indicate that it was more palatable.

Morpa and Common (Soil Conservation Service strain A-67) belong to the "curvula" type of Eragrostis (Leigh, 1961) and reproduce by apomixis. Morpa was released in 1970 (Voigt, 1971), and seed is now commercially available. In the past, Common constituted most of the unnamed lovegrass grown in the United States.

Although Morpa was more palatable, the question remained: Would cattle pastured on it produce more beef than those on Common? Our experimental objective was to compare the beef-producing value, adaptation to the arca, and management requirements of Morpa and Common.

\section{Experimental Procedure}

We compared Morpa and Common lovegrass in two studies made on the Southern Plains Experimental Range in

The authors are range scientist, agronomist, and research geneticist, Agricultural Research Service, U.S. Department of Agriculture, U.S. Southern Great Plains Field Station, Woodward, Oklahoma 73801 . The current address of Shoop is Crops Research Laboratory, CSU, Fort Collins, Colorado.

The research is a cooperative investigation of the Agricultural Research Service, U.S. Department of Agriculture and the Oklahoma Agricultural Experiment Station, Stillwater.

Manuscript received February 27, 1975. northwestern Oklahoma: a grazing study and a hay feeding study. The two studies were conducted independently, except that the hay in the feeding study was from opportunity harvests from the pastures used in the grazing study.

The experimental area was located on Pratt-loamy-fine-sand soil (Nance, 1960). The 85-year average yearly precipitation is 23 inches. Sixteen inches of this falls during the growing season, April through September. During the experiment, 1968 and 1969 were abnormally dry in midsummer. A 50-day drouth occurred in 1968 when precipitation was only $52 \%$ of the average for the period. In 1969, a 75-day drouth occurred when rainfall was only $38 \%$ of the average. The mean temperature is about $36^{\circ} \mathrm{F}$ in January-February and $80^{\circ} \mathrm{F}$ in July-August.

Four 6-acre pastures of Morpa and four of Common lovegrass were planted on May 14-18, 1965. The pastures were laid out so as to create four replications of a randomized-complete-block design for vegetation studies. For grazing, two pastures of each grass were combined to give two replications.

A uniform herd of Hereford steer calves weighing about $465 \mathrm{lb} /$ head was obtained each October from the same ranch. The calves were allotted to treatments at random within weight classes. They were individually weighed at the start and end of each year's trial and at the end of each month. Each calf was fed $1.5 \mathrm{lb} /$ day of $41 \%$ protein cottonsced pellets during the winter. Salt was the only other supplement fed.

\section{Grazing Study}

The grazing trials started on an average date of November 19 and ended on August 24 during the three grazing years 1967-69. Winter grazing continued until the grass was eaten or spring growth started, about March 15; then the steers were fed hay that had been harvested from surplus forage in the experimental pastures. Summer grazing started when the new grass was about 6 inches tall, about May 10.

By the start of spring grazing, nearly all forage produced the previous year had been removed by winter grazing, spring mowing, or spring burning (McIlvain and Shoop, 1970). The pastures were fertilized each year with an average of $50 \mathrm{lb} /$ acre of nitrogen $(\mathrm{N})$ from urea. The $\mathrm{N}$ was applied in a single application in 1967 and in two applications per year in 1968 and 1969.

The original 6-acre pastures were subdivided, and each replication of steers was rotated among its assigned subdivisions during the growing season. A pasture subdivision was grazed for about 14 days during each rotation cycle the first 2 years and for 6 days the last year. The stocking density with which each subdivision was grazed was $1.3,2.7$, and 8.0 steers/acre during 1967, 1968, and 1969, respectively.

Pastures were usually rested for 30-40 days between grazings so the new growth could reach 12-16 inches in height. However, sometimes the grass was more mature when grazing started. 
In most cases, each pasture subdivision was mowed once each summer. The mowing was done to remove excess grass as hay or to remove overly coarse grass left after a subdivision was grazed. The grass was grazed or mowed to a stubble height of about 4 inches in most instances.

\section{Hay Feeding Study}

Morpa hay was fed in direct comparison with Common lovegrass hay during each of the three winters, 1967-69. The hay was "opportunity-hay" harvested from subdivisions of the pastures used in the otherwise independent grazing study. As opportunity-hay, it was coarser and more mature than normal hay.

The three trials lasted an average of 104 days each. Duplicate five-head lots of steers were fed each variety of hay. Before each trial, the steers were pastured together on native range for 6-10 weeks and then preconditioned to lovegrass hay for 2 weeks. All hay was fed in mangers covered by a shed, and the orts were weighed back.

\section{Results and Discussion}

\section{Grazing Study}

Steers pastured on Morpa gained $305 \mathrm{lb} /$ head/year, whereas those pastured on Common gained $272 \mathrm{lb}$ (Table 1). Thus, Morpa increased the gain per steer an average of $12 \%$ during both winter and summer as compared with Common lovegrass.

Table 1. Gain per steer (lb) on 'Morpa' and 'Common' weeping lovegrass, 1967-69.

\begin{tabular}{lccc}
\hline Trial & Morpa & Common & LSD 0.05 \\
\hline Pasture trials & & & \\
Winter & 117 & 102 & 11 \\
Summer & 188 & 170 & 14 \\
Total & 305 & 272 & 8 \\
Hay trials & & & \\
Dec.-Mar. & 75 & 70 & N.S. \\
\hline
\end{tabular}

The increase in gain per steer produced by Morpa became larger in each of the 3 succeeding years. During 1967-69, respectively, steers on Morpa gained 18,36, and $44 \mathrm{lb} /$ head, or 6,13 , and $19 \%$ more than steers on Common. However, this interaction of strains with years was not statistically significant.

As a 3-year average, Morpa produced greater steer gains than Common during each of the five grazing periods of the year (Fig. 1). Statistically, the greater gains on Morpa were significant only for the periods May 13 to June 30 (0.05 level) and June 30 to August 24 (0.01 level).

Gains of steers on both strains of lovegrass compared favorably with gains of steers on native range during those periods when the lovegrass was not over 40 days of age and when ample forage was available. However, gains on both strains of lovegrass fell rapidly as forage maturity increased beyond 40 days. Because we were learning as we proceeded, the gains obtained in this experiment were lower than those that could be obtained by using management methods now known (McIlvain and Shoop, 1970). For example, in a later study during 1971, steers that grazed lovegrass whenever it was available (about half of the grazing year) and native range the balance of the time gained $397 \mathrm{lb} / \mathrm{head}$-the same as steers grazed continuously on native range.

The carrying capacities of Morpa and Common were equal. Both were stocked identically at a 3-year average of 1.7 acres/steer during a 278-day grazing year. Also, the amount of

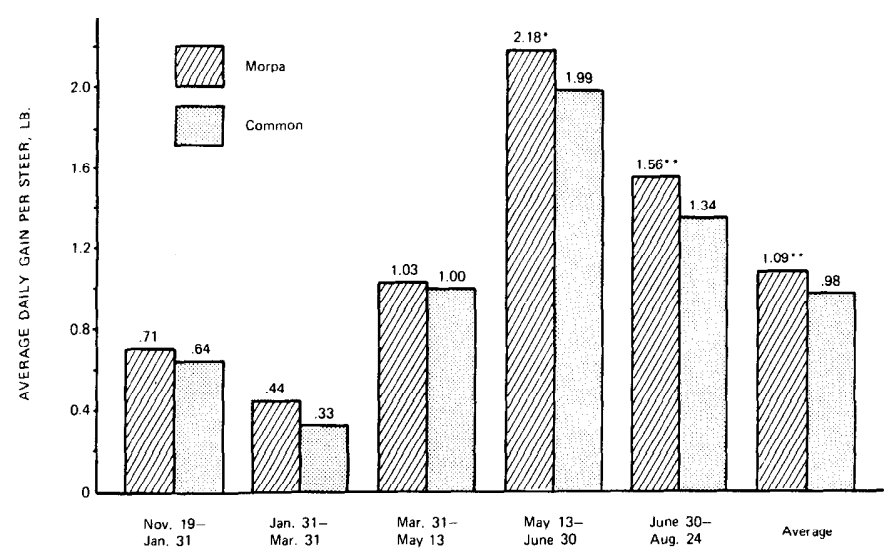

Fig. 1. Average daily gain of steers pastured on 'Morpa' and 'Common' weeping lovegrass, $1966-67$ to $1968-69$.

hay harvested was the same for both strains, an average of $1,400 \mathrm{lb} / a c r e$ annually. The potential stocking rate was reduced by drouth during 1968 and 1969 and by understocking because we did not know how to manage lovegrass as intensive pasture. As evidence, the average stocking rate was 0.75 acres/steer during the last year of this study.

Morpa lovegrass increased annual profits from grazing $\$ 12 /$ acre over those of Common lovegrass. Returns above costs were $\$ 19 /$ acre from Morpa and \$7/acre from Common. Thus, Morpa increased profit $170 \%$. All of the increased profit was due to the $33-1 b$ greater gain per head produced by Morpa (Table 2).

Table 2. Net returns from steers on 'Morpa' and 'Common' weeping lovegrass.

\begin{tabular}{lcc}
\hline Item & Morpa & Common \\
\hline Purchase weight, lb/steer & 465 & 465 \\
Purchase cost, \$/steer & 149 & 149 \\
Yearlong gain, lb/steer & 305 & 272 \\
Sales weight, lb/steer & 770 & 737 \\
Sales value, \$/steer & 215 & 206 \\
Total costs, \$/steer & 201 & 201 \\
Net returns, \$/steer & 14 & 5 \\
Net returns, \$/acre & 19 & 7 \\
\hline
\end{tabular}

${ }^{1}$ Costs, in addition to steer purchase, were death and veterinary; buying; hauling; selling; tax on steer; cottonseed cake; salt; pickup, horse, and miscellaneous costs; interests on steer and other costs; fertilizer; and labor.

${ }^{2}$ Based on the optimum stocking rate, as determined during the last year of the st udy and a later 3-year experiment on the pastures.

\section{Hay Feeding Study}

Steers fed the Morpa opportunity hay consumed 9.6 $\mathrm{lb} /$ head daily and gained $75 \mathrm{lb} /$ head during 104 days. In comparison, those fed the Common hay consumed $9.2 \mathrm{lb}$ and gained $70 \mathrm{lb}$ (Table 1). These differences are not statistically significant. However, these data are highly similar to those obtained during the three hay-feeding periods (March 15-May 10) of the grazing study. Thus, the steers ate slightly more Morpa hay and gained slightly more weight.

The average intake of lovegrass hay, $9.4 \mathrm{lb}$ by $520-1 \mathrm{~b}$ steers, compared relatively favorably with the amount of hay of medium quality that cattle have been observed to consume, about $2 \%$ of body weight (Crampton and Harris, 1969). Average daily consumption of hay per steer and daily gain per 
steer during each trial were 11.6 and $1.0 \mathrm{lb}$ in $1967,8.1$ and 0.4 in 1968 , and 8.9 and 0.8 in 1969 .

The larger quantities of hay eaten and the satisfactory steer gains during 1967 resulted from first-growth lovegrass cut on June 9 , when the seed was in the dough. The lower consumption and lower gains during the next 2 years resulted from more mature hay cut during August 1967 and July 1968 from pastures that had been grazed once or twice earlier in the season without subsequent mowing.

\section{Other Comparisons}

\section{Adaptation}

Frequent close examination of Morpa and Common lovegrass revealed no differences in establishment or in reaction to grazing, burning, nitrogen, or drouth. Morpa was slightly less winterhardy than Common at Woodward. However, during the 16 years that Morpa was studied intensively at Woodward, this lesser winterhardiness was important only twice when the grass was defoliated in September, October, or November.

About $20 \%$ of the plants and tillers of both Morpa and Common were killed during the summer of 1968 by a combination of (1) application of over $40 \mathrm{lb} /$ acre of $\mathrm{N}$ in mid-May, (2) drouth, and (3) overmaturity of the grass. Permitting the grass to become overmature when fertilized with over $40 \mathrm{lb}$ of $\mathrm{N}$ apparently caused excessive transpiration that led to exhaustion of soil moisture. Mowed and unmowed grass fertilized with rates of $\mathrm{N}$ from 0 to $30 \mathrm{lb} /$ acre did not die.

\section{Management}

Morpa and Common lovegrass both required the same intensive management practices. However, along the northern and western edges of the area of lovegrass adaptation, Morpa especially must not be defoliated in September, October, or November. Defoliation by fall armyworms, [Spodoptera frugiperda (J. E. Smith)] in the fall of 1969 killed 25\% of the tillers of Morpa and $15 \%$ of the tillers of Common. Observations during the fall suggested that Morpa was preferentially eaten by the armyworms. Thus, the greater loss may have been due to greater fall defoliation of Morpa, rather than to an appreciable difference in winterhardiness.

\section{Appearance}

Morpa was readily distinguishable from Common lovegrass when the seedheads of both strains were present. Morpa matured 7 to 10 days later and its seedheads were dark brownish-gray, whereas those of Common were light tan. Morpa was about 3 inches taller and had slightly wider leaves than Common. Both strains started growth at the same time in the spring and quit growth at the same time in the fall.

\section{Literature Cited}

Crampton, E. W., and L. E. Harris. 1969. Applied animal nutrition. 2nd ed. W. H. Freeman \& Co., San Francisco, Calif.

Leigh, J. H. 1961. Leaf anatomy in certain strains of Eragrostis (Beauv.). J. South Africa Bot. 27:141-146.

Mcllvain, E. H., and M. C. Shoop. 1970. Grazing weeping lovegrass. Okla. State Univ., OSU Extension Facts No. 2558. 4 p.

Nance, Earl C. 1960. Soil survey of Harper County, Oklahoma. U.S. Dep. Agr. Scrics 1956, No. 8.

Voigt, P. W. 1971. Registration of Morpa weeping lovegrass. Crop Sci. 11:312-313.

Voigt, P. W., W. R. Kneebone, E. H. Mcllvain, M. C. Shoop, and J. E. Webster. 1970. Palatability, chemical composition, and animal gains from selections of weeping lovegrass, Eragrost is curvula (Schrad.) Nees. Agron. J. 62:673-676. 